\title{
Coordination Compounds of Platinum and Palladium with Mixed Ligands (Usnic Acid and 1-(o-Tolyl) Biguanide) - Synthesis, Spectral Characterization and Biological Activity
}

\author{
MIRELA CALINESCU ${ }^{1 \#, ~ O V I D I U ~ O P R E A ~}{ }^{2 \#}$, CATALINA STOICA ${ }^{3}$, MIHAI NITA-LAZAR ${ }^{3}$, \\ MADALINA MIHALACHE ${ }^{2,3 *}$ \\ ${ }^{1}$ University of Bucharest, Faculty of Chemistry, Department of Inorganic Chemistry, 23 Dumbrava Rosie Str., 020462, \\ Bucharest, Romania \\ ${ }^{2}$ Department of Inorganic Chemistry, Chemistry-Physics and Electrochemistry, Faculty of Applied Chemistry and \\ Materials Science, University Politehnica of Bucharest, 1-7 Polizu Str., 011061, Bucharest, Romania \\ ${ }^{3}$ National Research and Development Institute for Industrial Ecology-ECOIND, 71-72 Drumul Podu Dambovitei Str., \\ 060652,Bucharest, Romania
}

Abstract: Four coordination compounds of Pd(II), Pt(II) and Pt(IV) with usnic acid $\left(\mathrm{H}_{3} \mathrm{AU}\right)$ and 1-(otolyl)biguanide $(T B)$ as ligands have been synthesized in view of their potential as antimicrobial, antifungal and antitumor agents. The metal complexes have been characterized by elemental and thermogravimetrical analyses, infrared and electronic spectra. Based on these studies, the following formulas have been proposed for the complexes: [Pd(TB)( $\left.\left.\mathrm{H}_{3} A U\right)\right]\left[\mathrm{PdCl}_{4}\right](\mathrm{Cl}),\left[\mathrm{Pd}(\mathrm{TB})\left(\mathrm{H}_{2} \mathrm{AU}\right)\right]$ $\mathrm{CH}_{3} \mathrm{COO}(\mathrm{C2}),\left[\mathrm{Pt}(\mathrm{TB})\left(\mathrm{H}_{2} \mathrm{AU}\right) \mathrm{Cl}_{2}\right] \mathrm{Cl}(\mathrm{C3})$ and $\left[\mathrm{Pt}(\mathrm{TB})\left(\mathrm{H}_{2} \mathrm{AU}\right)\right] \mathrm{Cl}(\mathrm{C4})$, where $\mathrm{H}_{2} \mathrm{AU}$ is deprotonated usnic acid. The in vitro biological activities of the new complexes were tested against Staphylococcus aureus ATCC 25923, Pseudomonas aeruginosa ATCC 27853, Candida albicans ATCC 10231 and HeLa tumor cells. All complexes were found to have good biological properties and therefore they can be further explored in therapeutic applications.

Keywords: biguanides, usnic acid, coordination compounds, biological activity

\section{Introduction}

Biguanides and related compounds have remained an important area of research, especially for their wide applications, due to their antibacterial, antifungal, antimalarial, hypoglycemic or antitumor activities [1-8]. Biguanides have also a remarkable coordination capability to various metal ions and the resulting complexes have often higher biological activity than ligands [9-11].

Thus, some coordination compounds of palladium and platinum with biguanides, such as $\left[\mathrm{Pd}\left(\mathrm{C}_{2} \mathrm{H}_{6} \mathrm{~N}_{5}\right)_{2}\right] \cdot \mathrm{H}_{2} \mathrm{O}, \quad\left[\mathrm{Pd}(\mathrm{HDMBG})_{2}\right] \mathrm{Cl}_{2} \cdot \mathrm{H}_{2} \mathrm{O}, \quad\left[\mathrm{PdL}^{1}\right] \mathrm{Cl}_{2} \cdot 0.5 \mathrm{H}_{2} \mathrm{O}$ and $\left[\mathrm{PdL}^{2}\right] \mathrm{Cl}_{2} \cdot 1.5 \mathrm{H}_{2} \mathrm{O}$ (where HDMBG: dimethylbiguanide, $\left.\mathrm{L}^{1}: \quad \mathrm{C}_{12} \mathrm{H}_{28} \mathrm{~N}_{12}, \quad \mathrm{~L}^{2}: \mathrm{C}_{12} \mathrm{H}_{30} \mathrm{~N}_{14}\right), \quad[\mathrm{Pd}(\mathrm{CHX})]\left[\mathrm{PdCl}_{4}\right] \cdot 2 \mathrm{H}_{2} \mathrm{O}$, $[\mathrm{Pd}(\mathrm{CHX})]\left(\mathrm{CH}_{3} \mathrm{COO}\right)_{2}, \quad\left[\mathrm{PtCl}_{4}\left(\mathrm{C}_{4} \mathrm{H}_{11} \mathrm{~N}_{5}\right)\right] \cdot \mathrm{C}_{2} \mathrm{H}_{6} \mathrm{OS}$ (where $\mathrm{CHX}$ : chlorhexidine), have been synthesized and tested for their biological activity [12-15].

On the other hand, the usnic acid shows also a wide range of biological properties, such as antibiotic, antiviral, antibacterial, apoptotic, analgesic and anti-inflammatory activities [16-27]. The usnic acid was the most effective antibiotic in lichens and appears to be an exclusive lichen product. Up to now, no synthetic derivative more effective than the natural form is known [28-29]. Literature survey revealed some metal complexes with usnic acid or its derivatives as ligands [30-34].

Lauterwein et al. (1995) stated that usnic acid is effective in vitro against staphylococci, enterococci and anaerobic bacteria strains from American Type Culture Collection (ATCC) [35]. The two usnic acid enantiomers tested against Enterococcus faecalis, Enterococcus faecium and Staphylococcus aureus strains showed a high level of antimicrobial activity [35]. 
In addition, the compound obtained from acyl hydrazone and usnic acid has good activity against Mycobacterium tuberculosis (Koch's bacillus) [36].

Usnic acid (-) showed moderate activity in the P388 (murine leukemia) assay and in vitro cytotoxic activity against L1210 cell lines [37].

Copper(II) complexes synthesized with ligands obtained by condensation of the usnic acid with acyl hydrazides of $\alpha$-naphthoic, caprylic and oxamic acids, as well as thiosemicarbazone derivatives were tested against Gram-negative bacteria (Escherichia coli) and Gram-positive bacteria (Staphylococcus aureus). The antibacterial activity proved to be higher for the complexes than that for the ligands and the $\mathrm{Cu}(\mathrm{II})$ ion [33].

Moreover, new synthesized $\mathrm{Pd}(\mathrm{II})$ and $\mathrm{Cu}$ (II) complexes with ligands obtained by condensation of usnic acid and hydrazide showed significant biological activity against Aspergillus niger, Escherichia coli, Pseudomonas aeruginosa and Bacillus subtilis strains as well as cytotoxic activity against HeLa cells of human cervical carcinoma [32].

Most bacteria are very resistant and adaptive microorganisms to environmental changes mainly due to their defense mechanism based on the efflux pumps which eliminate the toxic compounds from inside cells. Bacteria could have different defense response based on the presence of harmful compounds in the environment [38,39]. Various bacterial strains (Pseudomonas aeruginosa, Staphylococcus warneri and Pseudomonas aurantica) proved to be very effective in Reldan EC40 pesticide (Nita-Lazar et al. [40]) and pharmaceutical compounds metabolisation (Nita-Lazar et al. [41]).

In this paper we report the synthesis of four coordination compounds of palladium and platinum with mixed ligands: usnic acid and 1-(o-tolyl)biguanide, as well as their analytical and spectral characterization and biological activity screening.

\section{Materials and methods}

\subsection{Synthesis of the complexes}

The following chemical reagents were used for the synthesis of the four complexes: usnic acid,1(o-tolyl)biguanide, $\mathrm{PdCl}_{2}, \mathrm{Pd}\left(\mathrm{CH}_{3} \mathrm{COO}\right)_{2}, \mathrm{H}_{2} \mathrm{PtCl}_{6}, \mathrm{PtCl}_{2}, \mathrm{C}_{2} \mathrm{H}_{5} \mathrm{OH}$ and $\left(\mathrm{C}_{2} \mathrm{H}_{5}\right)_{2} \mathrm{O}$. All the chemicals used were of reagent grade and were purchased from Merck, Alfa Aesar and Sigma-Aldrich. The molar ratio metallic salt: usnic acid: 1-(o-tolyl)biguanide was 2:1:1, this ratio being subsequentely found only in the $\mathrm{C} 1$ complex.

For the synthesis of complexes $\left[\mathrm{Pd}(\mathrm{TB})\left(\mathrm{H}_{3} \mathrm{AU}\right)\right]\left[\mathrm{PdCl}_{4}\right](\mathrm{C} 1)$ and $\left[\mathrm{Pt}(\mathrm{TB})\left(\mathrm{H}_{2} \mathrm{AU}\right)\right] \mathrm{Cl}(\mathrm{C} 4)$, palladium chloride and platinum chloride, respectively, were refluxed with acetonitrile for $5 \mathrm{~h}$ at 50 $60^{\circ} \mathrm{C}$, to obtain more reactive compounds, according to the reactions:

$$
\begin{aligned}
& \mathrm{PdCl}_{2}+2 \mathrm{CH}_{3} \mathrm{CN} \rightarrow \mathrm{PdCl}_{2}\left(\mathrm{CH}_{3} \mathrm{CN}\right)_{2} \\
& \mathrm{PtCl}_{2}+2 \mathrm{CH}_{3} \mathrm{CN} \rightarrow \mathrm{PtCl}_{2}\left(\mathrm{CH}_{3} \mathrm{CN}\right)_{2}
\end{aligned}
$$

To these solutions, an ethanolic solution of the two ligands was added dropwise, with stirring. The resulting mixtures were stirred for $1 \mathrm{~h}$, when solid products were separated out.

Synthesis of complexes $\left[\mathrm{Pd}(\mathrm{TB})\left(\mathrm{H}_{2} \mathrm{AU}\right)\right] \mathrm{CH}_{3} \mathrm{COO}(\mathrm{C} 2)$ and $\left[\mathrm{Pt}(\mathrm{TB})\left(\mathrm{H}_{2} \mathrm{AU}\right) \mathrm{Cl}_{2}\right] \mathrm{Cl}$ (C3): the ligands were dissolved in ethanol, under slight heating; the required metal salt, i.e., $\operatorname{Pd}\left(\mathrm{CH}_{3} \mathrm{COO}\right)_{2}$ and $\mathrm{H}_{2} \mathrm{PtCl}_{6}$, respectively, dissolved in a minimal amount of ethanol, was added slowly under stirring, to the solution of the ligands. After two hours of stirring, the complexes were obtained as a precipitate.

The synthesized complexes were filtered off, washed with ethyl ether and dried under air. The compounds had a high degree of purity, so they did not require further purification.

\subsection{Physical-chemical characterization of the complexes}

The percentages of $\mathrm{C}, \mathrm{N}$ and $\mathrm{H}$ in the composition of the four complexes were analyzed using Flash 2000 Elemental Analyzer. Palladium and platinum content was determined using a Perkin Elmer Aanalyst 400 atomic absorption spectrophotometer. 
Thermal analyses were performed with a simultaneous thermogravimetric analysis/differential scanning calorimetry (STA/DSC) $449 \mathrm{~F} 1$ Jupiter working in a dynamic air atmosphere at a flow rate of $20 \mathrm{~mL} / \mathrm{min}$ and at a heating rate of $10^{\circ} \mathrm{C} / \mathrm{min}$ up to $900^{\circ} \mathrm{C}$.

The UV-Vis diffuse reflectance spectra were recorded on a Jasco V670 spectrometer, in the range of 200-800 nm, using $\mathrm{MgO}$ as standard.

The infrared spectra were recorded on a Nicolet IS 50 FT-IR spectrophotometer, in the range $4000-200 \mathrm{~cm}^{-1}$.

\subsection{Biological activity}

The biological activity of the ligands and C1-C4 complexes was tested in vitro against two Grampositive and Gram-negative bacterial strains (Staphylococcus aureus ATCC 25923 and Pseudomonas aeruginosa ATCC 27853), one fungal strain (Candida albicans ATCC 10231) and HeLa cells.

The antimicrobial and antifungal activities were quantified based on bacterial and fungal growth inhibition monitored by spectrophotometric determination at $620 \mathrm{~nm}$. A quantitative method was used, based on the production of binary serial microdilutions. The working range was $1.00-0.0019 \mathrm{mg} / \mathrm{mL}$ and the solvent used was DMSO.

Antitumor activity of newly synthesized complexes and ligands was determined by MTT assay (MTT tetrazolium reagent (3-(4,5-dimethylthiazol-2-yl)-2,5-diphenyltetrazolium)). The cellular metabolic activity was linked to the reduction of MTT tetrazolium reagent (3-(4,5-dimethylthiazol-2yl)-2,5-diphenyltetrazolium) to an insoluble formazan compound.

This process was NAD(P)H-dependent cellular oxidoreductases and spectrophotometrically monitored at a wavelength of $570 \mathrm{~nm}$.

The detection of biological activity was performed according with the methods described by Mihalache et al. [42].

\section{Results and discussions}

\subsection{Elemental analysis}

To determine the molecular formulas of the four complexes, the percentages of carbon, nitrogen, hydrogen were determined by elemental analysis and the metal content by molecular absorption spectrometry. The differences between the percentages obtained experimentally and those calculated were very small.

$\left[\mathrm{Pd}(\mathrm{TB})\left(\mathrm{H}_{3} \mathrm{AU}\right)\right]\left[\mathrm{PdCl}_{4}\right] \quad$ Found $(\%): \mathrm{C}, 36.26 ; \mathrm{H}, 3.19 ; \mathrm{N}, 7.45 ; \mathrm{Pd}, 23.77$.

Calculated (\%): C, 36.43; H, 3.28; N, 7.87; Pd, 23.91.

$\left[\mathrm{Pd}(\mathrm{TB})\left(\mathrm{H}_{2} \mathrm{AU}\right)\right] \mathrm{CH}_{3} \mathrm{COO} \quad$ Found $(\%): \mathrm{C}, 49.93 ; \mathrm{H}, 4.38 ; \mathrm{N}, 10.11 ; \mathrm{Pd}, 15.31$.

Calculated (\%): C, 49.76; H, 4.46; N, 10.00; Pd, 15.20.

$\left[\mathrm{Pt}(\mathrm{TB})\left(\mathrm{H}_{2} \mathrm{AU}\right) \mathrm{Cl}_{2}\right] \mathrm{Cl} \quad$ Found $(\%): \mathrm{C}, 38.91 ; \mathrm{H}, 3.51 ; \mathrm{N}, 8.59 ; \mathrm{Pt}, 23.42$.

Calculated (\%): C, 38.79; H, 3.38; N, 8.38; Pt, 23.34.

$\left[\mathrm{Pt}(\mathrm{TB})\left(\mathrm{H}_{2} \mathrm{AU}\right)\right] \mathrm{Cl} \quad$ Found $(\%): \mathrm{C}, 42.13 ; \mathrm{H}, 3.96 ; \mathrm{N}, 9.21 ; \mathrm{Pt}, 25.67$.

Calculated (\%): C, 42.33; H, 3.82; N, 9.14; Pt, 25.46.

\subsection{Thermal analysis}

The thermograms obtained from the thermal decomposition of complexes C1-C4 gave information's regarding the mass losses and the thermal effects that accompany them.

The TG curves of the palladium (II) complexes indicate that these compounds are stable to $220^{\circ} \mathrm{C}$, when it starts their decomposition. This indicates that neither of the two complexes has water or alcohol in the molecule. Above this temperature, oxidative degradation of the complexes takes place. The final residue resulting from the thermal decomposition of the two complexes is palladium [43].

As for the previous two compounds, the $\mathrm{C} 3$ and $\mathrm{C} 4$ complexes are stable over a large temperature range $\left(30-200^{\circ} \mathrm{C}\right)$, which confirms that they do not contain water or alcohol. Above this temperature the complexes undergo decomposition. For the two complexes, the slightly endothermic process, 
without mass loss, at $210^{\circ} \mathrm{C}$, could be attributed to their melting. The large, highly exothermic process, occurring between 400 and $500^{\circ} \mathrm{C}$ is due to oxidative degradation and elimination of the organic ligands. The final residue is platinum [44].

\subsection{Ultraviolet-visible spectra}

Based on the UV-Vis spectra of the complexes compared to the ligands used in the synthesis, their stereochemistry was established. The electronic $d-d$ transitions observed in the spectra of the complexes with their assignments and the corresponding symmetry are given in Table1.

The electronic spectra of the complexes $\mathrm{C} 1$ and $\mathrm{C} 2$ exhibited a strong absorption band, with maximum at $25975 \mathrm{~cm}^{-1}$ and $26315 \mathrm{~cm}^{-1}$, respectively, that can be attributed to ${ }^{1} \mathrm{~A}_{1 \mathrm{~g}} \rightarrow{ }^{1} \mathrm{~B}_{1 \mathrm{~g}}$ transition.

In the case of $\mathrm{C} 1$ complex the band at $19230 \mathrm{~cm}^{-1}$ corresponds to the transition ${ }^{1} \mathrm{~A}_{1 \mathrm{~g}} \rightarrow{ }^{1} \mathrm{~A}_{2 \mathrm{~g}}$. The same assignment corresponds to the shoulder in the spectrum of the $\mathrm{C} 2$ complex located at $19610 \mathrm{~cm}^{-1}$.

According to the experimental data and to the literature reports, the symmetry proposed for these two complexes is square planar $[45,46]$.

$\mathrm{C} 3$ and $\mathrm{C} 4$ complexes contain platinum in different oxidation states, namely $+\mathrm{IV}$ in $\mathrm{C} 3$ and $+\mathrm{II}$ in C4. It was found that platinum maintained its valence in the substances used in synthesis: $\mathrm{H}_{2} \mathrm{PtCl}_{6}$ for $\mathrm{C} 3$ and $\mathrm{PtCl}_{2}$ in $\mathrm{C} 4$.

In the UV-Vis spectrum of the $\mathrm{C} 3$ complex the three bands observed at $17095 \mathrm{~cm}^{-1}, 22990 \mathrm{~cm}^{-1}$ and $28570 \mathrm{~cm}^{-1}$ can be attributed to the $\mathrm{d}-\mathrm{d}$ transitions from the ground state ${ }^{1} \mathrm{~A}_{1 \mathrm{~g}}$ to ${ }^{1} \mathrm{~T}_{1 \mathrm{~g}},{ }^{1} \mathrm{~T}_{2 \mathrm{~g}}$ and ${ }^{3} \mathrm{~T}_{1 \mathrm{~g}}$, respectively, according to an octahedral symmetry.

For the $\mathrm{C} 4$ complex the symmetry proposed is square-planar, as confirmed by the bands at 20830 $\mathrm{cm}^{-1}$ and $25640 \mathrm{~cm}^{-1}$ which are assigned to ${ }^{1} \mathrm{~A}_{1 \mathrm{~g}} \rightarrow{ }^{1} \mathrm{~A}_{2 \mathrm{~g}}$ and ${ }^{1} \mathrm{~A}_{1 \mathrm{~g}} \rightarrow{ }^{1} \mathrm{~B}_{1 \mathrm{~g}}$ transitions.

Table 1. Maxima of $d-d$ absorption bands for $\mathrm{C} 1-\mathrm{C} 4$ complexes

\begin{tabular}{ccccc}
\hline Complex & \multicolumn{2}{c}{ Observed bands } & Assignments & Proposed \\
& $\lambda_{\max }(\mathbf{n m})$ & $\boldsymbol{v}\left(\mathbf{c m}^{-1}\right)$ & & stereochemistry \\
\hline \multirow{2}{*}[\mathrm{Pd}(\mathrm{TB})(\mathrm{H}_{3}\mathrm{AU})]{$\left[\mathrm{PdCl}_{4}\right]$} & 520 & 19230 & ${ }^{1} \mathrm{~A}_{1 \mathrm{~g}} \rightarrow{ }^{1} \mathrm{~A}_{2 \mathrm{~g}}$ & square-planar \\
\hline \multirow{2}{*}[\mathrm{Pd}(\mathrm{TB})(\mathrm{H}_{2}\mathrm{AU})]{$\mathrm{CH}_{3} \mathrm{COO}$} & 385 & 25975 & ${ }^{1} \mathrm{~A}_{1 \mathrm{~g}} \rightarrow{ }^{1} \mathrm{~B}_{1 \mathrm{~g}}$ & \\
\hline \multirow{2}{*}[\mathrm{Pt}(\mathrm{TB})(\mathrm{H}_{2}\mathrm{AU})\mathrm{Cl}\mathrm{Cl}_{2}]{$\mathrm{Cl}$} & 510 & 19610 & ${ }^{1} \mathrm{~A}_{1 \mathrm{~g}} \rightarrow{ }^{1} \mathrm{~A}_{2 \mathrm{~g}}$ & square-planar \\
& 380 & 26315 & ${ }^{1} \mathrm{~A}_{1 \mathrm{~g}} \rightarrow{ }^{1} \mathrm{~B}_{1 \mathrm{~g}}$ & \\
& 585 & 17095 & ${ }^{1} \mathrm{~A}_{1 \mathrm{~g}} \rightarrow{ }^{1} \mathrm{~T}_{1 \mathrm{~g}}$ & \\
& 435 & 22990 & ${ }^{1} \mathrm{~A}_{1 \mathrm{~g}} \rightarrow{ }^{1} \mathrm{~T}_{2 \mathrm{~g}}$ & octahedral \\
\hline \multirow{2}{*}[\mathrm{Pt}(\mathrm{TB})(\mathrm{H}_{2}\mathrm{AU})]{$\mathrm{Cl}$} & 350 & 28570 & ${ }^{1} \mathrm{~A}_{1 \mathrm{~g}} \rightarrow{ }^{3} \mathrm{~T}_{1 \mathrm{~g}}$ & \\
& 480 & 20830 & ${ }^{1} \mathrm{~A}_{1 \mathrm{~g}} \rightarrow{ }^{1} \mathrm{~A}_{2 \mathrm{~g}}$ & \multirow{2}{*}{ square-planar } \\
\hline
\end{tabular}

\subsection{FT-IR Spectra}

Comparative analysis of the IR spectra of the usnic acid and 1-(o-tolyl)biguanide and their metal complexes allows to establish the donor atoms of the ligands in coordination to the metal ions. The assignments of the spectral bands characteristic of the ligands and the complexes $\mathrm{C} 1-\mathrm{C} 4$ are presented in Table 2.

The strong band appearing at $1676 \mathrm{~cm}^{-1}$ in the IR spectrum of the usnic acid may be assigned to the stretching vibration $v(\mathrm{C}=\mathrm{O})$ of the ketone function $[47,48]$. This band shifts to lower wave numbers in the IR spectra of all complexes, indicating the coordination of the usnic acid through the ketone oxygen atoms.

The very strong band, with maximum at $1191 \mathrm{~cm}^{-1}$, may be assigned to the stretching vibration of $\mathrm{C}-\mathrm{O}_{\text {phenolic }}$ [49]. Its position is practically unchanged in the spectrum of the complex $\mathrm{C} 1$, but it is shifted to higher wavenumbers in the spectra of the complexes $\mathrm{C} 2-\mathrm{C} 4$. These observations suggest the deprotonation of the usnic acid in the complexes $\mathrm{C} 2-\mathrm{C} 4$ and coordination through phenolic oxygen linked to carbon 3 . Thus, the usnic acid acts as neutre bidentate $\mathrm{OO}$ donor in the complex $\mathrm{C} 1$ and as a monobasic bidentate $\mathrm{OO}$ donor in the complexes $\mathrm{C} 2-\mathrm{C} 4$.

The band due to the stretching vibration of the imine group, $v(\mathrm{C}=\mathrm{N})$, appearing at $1610 \mathrm{~cm}^{-1}$ in the IR spectrum of 1-(o-tolyl)biguanide, shows a downward shift in the spectra of the complexes C2-C4 
and an upward shift in the spectrum of the complex $\mathrm{C}$. These observations are in according to the involvement of imine nitrogen atoms in coordination to the metal ions [49].

In the IR spectrum of the complex $\mathrm{C} 2$ a new strong absorption band at $1395 \mathrm{~cm}^{-1}$ may be assigned to $v_{\text {sym }}(\mathrm{COO})$ of acetate group. The strong absorption band at $1552 \mathrm{~cm}^{-1}$ in the spectrum of the same complex is due to $v_{\text {asym }}(\mathrm{COO})$, the value of $\Delta=v_{\text {asym }}(\mathrm{COO})-v_{\text {sym }}(\mathrm{COO})=157 \mathrm{~cm}^{-1}$ being in the range of ionic acetate [50].

Table 2. IR bands and their assignments for the synthesized complexes and ligands $\left(\bar{v}_{\max }, \mathrm{cm}^{-1}\right)$

\begin{tabular}{|c|c|c|c|c|c|c|}
\hline Assignments & $\begin{array}{l}\text { 1-(o-tolyl) } \\
\text { biguanide }\end{array}$ & $\begin{array}{l}\text { usnic } \\
\text { acid }\end{array}$ & C1 & $\mathrm{C} 2$ & $\mathrm{C3}$ & $\mathrm{C4}$ \\
\hline$v(\mathrm{C}=\mathrm{O})$ keto of metyl ketone & & $1676 \mathrm{~s}$ & $1662 \mathrm{~s}$ & $1635 \mathrm{~s}$ & $1641 \mathrm{~s}$ & $1653 \mathrm{~s}$ \\
\hline$v(\mathrm{C}=\mathrm{N})$ & $1610 \mathrm{vs}$ & & $1645 \mathrm{vs}$ & 1602 vs & 1618 vs & $1624 \mathrm{vs}$ \\
\hline$\delta(\mathrm{NH})+v(\mathrm{C}-\mathrm{N})$ & $\begin{array}{l}1577 \mathrm{~m} \\
1270 \mathrm{w}\end{array}$ & & $\begin{array}{l}1590 \mathrm{~m} \\
1231 \mathrm{w}\end{array}$ & $\begin{array}{l}1589 \mathrm{~m} \\
1246 \mathrm{w}\end{array}$ & $\begin{array}{l}1557 \mathrm{~m} \\
1240 \mathrm{~m}\end{array}$ & $\begin{array}{l}1590 \mathrm{~m} \\
1265 \mathrm{w}\end{array}$ \\
\hline$v(\mathrm{CO})_{\text {phenolic }}$ & & $1191 \mathrm{vs}$ & $1197 \mathrm{vs}$ & $1220 \mathrm{vs}$ & 1217 vs & $1209 \mathrm{vs}$ \\
\hline$\delta(\mathrm{OH})$ phenolic outside the plan & & $700 \mathrm{~m}$ & $708 \mathrm{~m}$ & $716 \mathrm{~m}$ & $722 \mathrm{~m}$ & $729 \mathrm{~m}$ \\
\hline $\mathrm{M}-\mathrm{Cl}$ & & & $303 \mathrm{w}$ & & $279 \mathrm{w}$ & \\
\hline$\nu_{\text {asym }}(\mathrm{C}=\mathrm{O})_{\text {acetate }}$ & & & & $1552 \mathrm{~s}$ & & \\
\hline$v_{\text {sym }}(\mathrm{C}-\mathrm{O})_{\text {acetate }}$ & & & & $1395 \mathrm{~s}$ & & \\
\hline$v(\mathrm{M}-\mathrm{N})$ & & & $503 \mathrm{~m}$ & $532 \mathrm{~m}$ & $490 \mathrm{~m}$ & $521 \mathrm{~m}$ \\
\hline$v(\mathrm{M}-\mathrm{O})$ & & & $597 \mathrm{~m}$ & $602 w$ & $595 \mathrm{w}$ & $580 \mathrm{~m}$ \\
\hline
\end{tabular}

Supplementary bands appearing in the IR spectra of the complexes at low wave numbers may be assigned to the vibrations metal-donor atom: $v(\mathrm{M}-\mathrm{O})\left(580-602 \mathrm{~cm}^{-1}\right)$ and $v(\mathrm{M}-\mathrm{N})\left(490-521 \mathrm{~cm}^{-1}\right)$ [50].

Based on these data, the four coordination complexes are proposed to have the conformations shown in Figure 1.<smiles>CC(=O)c1c(O)c(C)c2c(c1O)C1(C)N[Pb](NC(N)=NC(Nc3ccccc3C)NC(C)(C)C)(C(C)=O)OC1=CC2=O</smiles>

$\left[\mathrm{Pd}(\mathrm{TB})\left(\mathrm{H}_{3} \mathrm{AU}\right)\right]\left[\mathrm{PdCl}_{4}\right](\mathbf{C 1})$<smiles>CC(=O)c1c(C)cc2c(c1O)C(=O)C1(C)C(=Cc3c(C)c(O)c(C(C)=O)c(O)c31)O2</smiles>

$\left[\mathrm{Pd}(\mathrm{TB})\left(\mathrm{H}_{2} \mathrm{AU}\right)\right] \mathrm{CH}_{3} \mathrm{COO}(\mathbf{C 2})$ 
<smiles>CC(=O)C1=C(OP(Cl)(Cl)(N=C(N)NC(N)Nc2ccccc2C)NC(=N)N)C=C2Oc3c(C)c(O)c(C(C)=O)c(O)c3C21C</smiles>

$\left[\mathrm{Pt}(\mathrm{TB})\left(\mathrm{H}_{2} \mathrm{AU}\right) \mathrm{Cl}_{2}\right] \mathrm{Cl}(\mathbf{C 3})$<smiles>CC(=O)c1c(O)c(C)c2c(c1O)C1(C)OC2=Cc2op(N/C(N)=N\Nc3ccccc3C)nc(N)[nH]c2C1=O</smiles>

$\left[\mathrm{Pt}(\mathrm{TB})\left(\mathrm{H}_{2} \mathrm{AU}\right)\right] \mathrm{Cl}(\mathbf{C} 4)$

Figure 1. Proposed formulas for C1-C4 complexes

\subsection{Antimicrobial activity}

C1-C4 complexes, $\mathrm{H}_{3} \mathrm{AU}$ and TB were tested in vitro against Staphylococcus aureus ATCC 25923 and Pseudomonas aeruginosa ATCC 27853 strains to determine antibacterial activity. Following the tests performed it was observed that the antimicrobial activity against the Gram positive species Staphylococcus aureus was very good for complexes and the usnic acid while for 1-(o-tolyl) biguanide was much weaker. Platinum complexes have the lowest minimum inhibitory concentration, 0.0019 $\mathrm{mg} / \mathrm{mL}$, four times lower than that of usnic acid.

In the case of Gram negative bacteria Pseudomonas aeruginosa both ligands have low antimicrobial activity. All complexes have a good activity against this strain, the tetravalent platinum complex having the lowest MIC of $0.0625 \mathrm{mg} / \mathrm{mL}$. The solvent used in dilutions did not influence the antimicrobial activity of the tested compounds at working concentrations.

The minimum inhibitory concentrations against the two bacterial strains for the usnic acid, 1-(otolyl)biguanide and the complexes synthesized are shown in Figures 2 and 3.

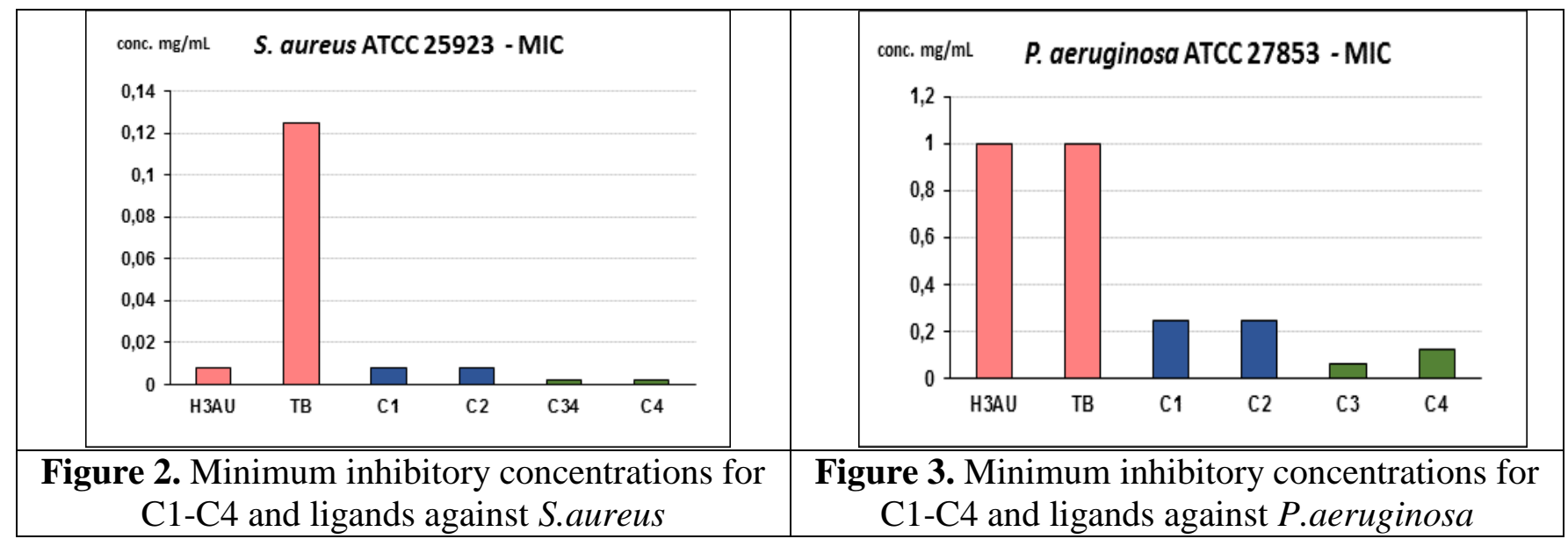




\subsection{Antifungal activity}

Antifungal activity of the ligands and the metal complexes was tested against Candida albicans ATCC 10231. The results indicate that the ligands have a poor activity, $\mathrm{C} 1$ and $\mathrm{C} 2$ complexes have a moderate one, while the platinum complexes have the best antifungal activity. The latter have a MIC of $0.125 \mathrm{mg} / \mathrm{mL}$.

The minimum inhibitory concentrations for ligands and C1-C4 complexes are shown in Figure 4.

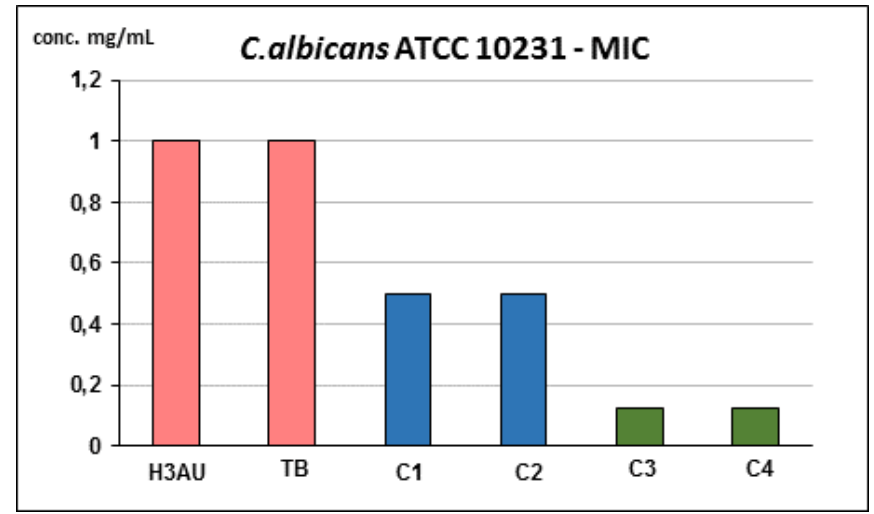

Figure 4. Minimum inhibitory concentrations for C1-C4 and ligands against C. albicans

\subsection{Antitumor activity}

Antitumor activity was tested on HeLa cells for the complexes and the ligands. The percentages of viability of these cells in the presence of the tested compounds were calculated relative to the untreated control sample. The solutions used for these samples had a concentration of $500 \mu \mathrm{g} / \mathrm{mL}$ and were incubated at $37^{\circ} \mathrm{C}$ for 24 hours.

Platinum complexes have reduced the viability of HeLa cells by $35 \% \mathrm{C} 3$ and $32 \% \mathrm{C} 4$, respectively, thus showing a good cytotoxic effect. The ligands and palladium complexes had a weaker effect on this type of tumor cells.

Figure 5 shows the viability of HeLa cells in the presence of ligands and complexes.

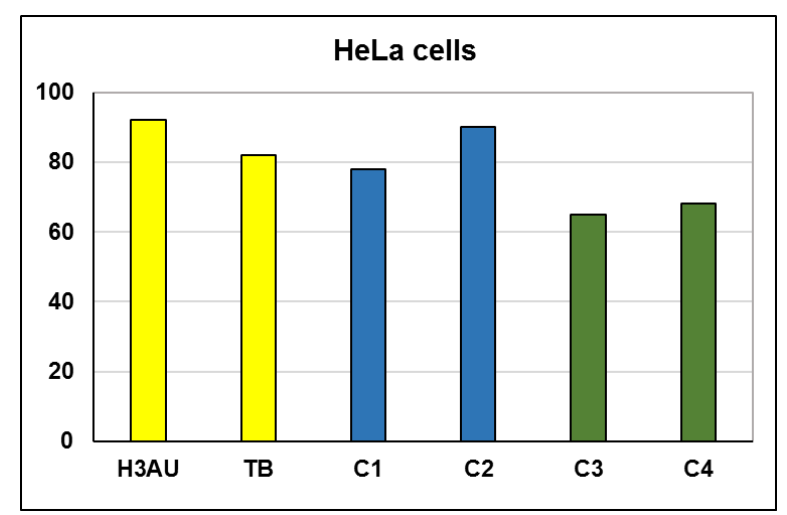

Figure 5. Viability of HeLa cell cultures in the presence of the ligands and complexes

\section{Conclusions}

Four new complexes of $\mathrm{Pd}(\mathrm{II}), \mathrm{Pt}(\mathrm{II})$ and $\mathrm{Pt}(\mathrm{IV})$ were obtained using usnic acid and 1-(otolyl)biguanide as ligands. The composition and the stereochemistry around the metal ions were established based on the analytical and spectral data. Pd(II) complexes have square planar symmetry, C3 complex contains tetravalent platinum and it has octahedral symmetry, while the complex C4 is square planar with divalent platinum. $\mathrm{C} 1$ is of the Vauquelin type, having a complex anion $\left[\mathrm{PdCl}_{4}\right]^{2-}$. 
The good antibacterial activity of the complexes against $S$. aureus is mainly due to the usnic acid found in their composition. Platinum complexes have a better activity against all tested strains compared to palladium complexes.

The antitumor activity of the $\mathrm{C} 1$ complex is better than the $\mathrm{C} 2$ and can be explained by the number of palladium ions in the molecule, namely, two for the first versus one for the second complex. As a general observation, the biological activity of the ligands is improved by complexation to the metal ions.

\section{Abbreviations:}
$\mathrm{H}_{3} \mathrm{AU}$
usnic acid
$\mathrm{H}_{2} \mathrm{AU}$
deprotonated usnic acid
TB 1-(o-tolyl)biguanide
DMSO dimethylsulfoxide
$\mathrm{NAD}(\mathrm{P}) \mathrm{H}$ nicotinamide-adenine-dinucleotide phosphate
MTT 3-(4,5-dimethylthiazol-2-yl) -2,5-diphenyltetrazolium bromide MIC Minimum Inhibitory Concentration

\section{References}

1. KAMARUZZAMAN, N.F., FIRDESSA, R., GOOD, L., Bactericidal effects of polyhexamethylene biguanide against intracellular Staphylococcus aureus EMRSA-15 and USA 300, J. Antimicrob. Chemother. 71(5), 2016, 1252-1259

2. ABBAS, S.Y., BASYOUNI, W.M., EL-BAYOUK, K.A.M., TOHAMY, W.M., ALY, H.F., ARAFA, A., SOLIMAN, M.S., New Biguanides as Anti-Diabetic Agents Part I: Synthesis and Evaluation of 1-Substituted Biguanide Derivatives as Anti-Diabetic Agents of Type II Diabetes Insulin Resistant, Drug Research, 2017, 67(10), 557-563

3. VIOLLET, B., GUIGAS, B., SANZ GARCIA, N., LECLERC, J., FORETZ, M., ANDREELLI, F., Cellular and molecular mechanisms of metformin: an overview, Clin. Sci. (Lond), 122(6), 2012, 253270

4. PATRON, L., GIURGINCA, M., PATRINOIU, G.M., IFTIMIE, N., MEGHEA, A., Influence of some therapeutically active biguanides and their metal complexes on the antioxidant activity, Rev. Roum. Chim., 50(6), 2005, 457-464

5. NARISE, K., OKUDA, K., ENOMOTO, Y., HIRAYAMA, T., NAGASAWA, H., Optimization of biguanide derivatives as selective antitumor agents blocking adaptive stress responses in the tumor microenvironment, Drug Des. Devel. Ther., 8, 2014, 701-717

6. POLLAK, M., Potential applications for biguanides in oncology, J. Clin. Invest., 123(9), 2013, 3693-3700

7. PELIN, A.M., GAVAT, C.C., BALAN, G., GEORGESCU, C.V., Pharmacological Principles Used in Patient Monitoring with Type 2 Diabetes, Rev. Chim., 68(2), 2017, 378-383

8. BOGDAN, M., TICA, I., GHEORGHE, D.N., SILOSI, I., SOLOMON, S., MARTU, I., SURLIN, P., CHISCOP, I., BUDACU, C., Effect of 0.2\% Chlorhexidine's Use for Treatment of Localized Gingival Lesions in Patients with Type 2 Diabetes, Rev. Chim., 67(12), 2016, 2651-2653

9. CALineSCU, M., STOICA, C., NITA-LAZAR, M., Complex Compounds of Sm(III) with Chlorhexidine Synthesis, characterization, luminescent properties and antibacterial activity, Rev. Chim., 70(1), 2019, 6-12

10. CALINESCU, M., NEGREANU-PIRJOL, T., GEORGESCU, R., CALINESCU, O., Synthesis and characterization of new copper (II) complex compounds with chlorhexidine. Part I., Chem. Eur. J., 8(3), 2010, 543-549

11. OLAR, R., BADEA, M., ILIS, M., NEGREANU-PIRJOL, T., CALINESCU, M., Studies on thermal behavior of some antibacterial copper (II) complex compounds with a dibiguanide derivative ligand, 
J. Therm. Anal. Calorim., 111(2), 2013, p.1189-1195

12. SU, Y.L., ZHU, M.L., Bis(biguanido- $\kappa 2 \mathrm{~N}, \mathrm{~N}^{\prime}$ )palladium(II) dihydrate, Acta Crystallogr. Sect.E, 62, 2006, 1188-1189

13. BADEA, M., IOSUB, E., CHIFIRIUC, C.M., MARUTESCU, L., IORGULESCU, E.E., LAZAR, V., MARINESCU, D., BLEOTU, C., OLAR, R., Thermal, spectral, electrochemical and biologic characterization of new $\mathrm{Pd}(\mathrm{II})$ complexes with ligands bearing biguanide moieties, J. Therm. Anal. Calorim., 111(3), 2013, 1753-1761

14.MIHALACHE, M., NEGREANU-PIRJOL, T., DUMITRASCU, F., DRAGHICI, C., CALINESCU, M., Synthesis, characterization and biological activity of new Ni(II), $\mathrm{Pd}(\mathrm{II})$ and $\mathrm{Cr}$ (III) complex compounds with chlorhexidine, J. Serb. Chem. Soc., 83(3), 2018, 271-284

15. BENTEFRIT, F., MORGANT, G., VIOSSAT, B., LEOUCE, S., GUILBAUD, N., PIERRE, A., ATASSI, G., Synthesis and antitumor activity of the metformin platinum (IV) complex. Crystal structure of the tetrachloro(metformin)platinum (IV) dimethylsulfoxide solvate, J. Inorg. Biochem., 68(1), 1997, 53-59

16. ARAÚJO, A.A.S., DE MELO, M.G.D., RABELO, T.K., NUNES, P.S., SANTOS, S.L., SERAFINI, M.R., SANTOS, M.R.V., QUINTANS-JÚNIOR, L.J., GELAIN, D.P., Review of the biological properties and toxicity of usnic acid, Nat. Prod. Res., 29(23), 2015, 2167-2180

17. COCCHIETTO, M., SKERT, N., NIMIS, P.L., SAVA, G., A review on usnic acid, an interesting natural Compound, Naturwissenschaften, 89(4), 2002, 137-146

18. KIM, K.J., JEONG, M.H., LEE, Y., HWANG, S.J., SHIN, H.B., HUR, J.S., SON, Y.J., Effect of Usnic Acid on Osteoclastogenic Activity, J. Clin. Med. 7(10), 2018, 345

19. CAMPANELlA, L., DELFINI, M., ERCOLE, P., IACOANGELI, A., RISULEO, G., Molecular characterization and action of usnic acid: a drug that inhibits proliferation of mouse polyomavirus in vitro and whose main target is RNA transcription, Biochimie, 84(4), 2002, 329-334

20. EMSEN, B., ASLAN, A., TURKEZ, H., JOUGHI, A. T., KAYA, A., The anti-cancer efficacies of diffractaic, lobaric, and usnic acid: In vitro inhibition of glioma, J. Cancer Res. Ther., 14(5), 2018, 941-951

21.BACKOROVA, M., JENDZELOVSKY, R., KELlO, M., BACKOR, M., MIKES, J., FEDOROCKO, P., Lichen secondary metabolites are responsible for induction of apoptosis in HT-29 and A2780 human cancer cell lines, Toxicol. in Vitro, 26(3), 2012, 462-468

22. BAZIN, M.A., LE LAMER, A.C., DELCROS, J.G., ROUAUD, I., URIAC, P., BOUSTIE, J., CORBEL, J.C., TOMASI, S., Synthesis and cytotoxic activities of usnic acid derivatives, Bioorg. Med. Chem., 16(14), 2008, 6860-6866

23. RAMIS, I.B., VIANNA, J.S., REIS, A.J., VON GROLL, A., RAMOS, D.F., VIVEIROS, M., DA SILVA, P.E.A., Antimicrobial and Efflux Inhibitor Activity of Usnic Acid Against Mycobacterium abscessus, Planta Med., 84(17), 2018, 1265-1270

24. CARDARElli, M., SERINO, G., CAMPANELlA, L., ERCOLE, P., NARDONE, F.D., ALESIANI, O., ROSSIELLO, F., Antimitotic effects of usnic acid on different biological systems, Cell. Mol. Life Sci., 53(8), 1997, 667-672

25. OKUYAMA, E., UMEYAMA, K., YAMAZAKI, M., KINOSHITA, Y., YAMAMOTO, Y., Usnic Acid and Diffractaic Acid as Analgesic and Antipyretic Components of Usnea-Diffracta, Planta Med., 61(2), 1995, 113-115

26.VIJAYAKUMARA， C.S., VISWANATHANA， S., KANNAPPA， U., REDDYA, M., PARVATHAVARTHINIA, S., KUNDUB, A.B., SUKUMARB, E., Anti-inflammatory activity of (+)usnic acid, Fitoterapia, 71, 2000, 564-566

27. VANGA, N.R., KOTA, A., SISTlA, R., UPPULURI, M., Synthesis and anti-inflammatory activity of novel triazole hybrids of (+)-usnic acid, the major dibenzofuran metabolite of the lichen Usnea longissimi, Mol. Divers., 21(2), 2017, 273-282

28. LAWREY, J.D., Biological Role of Lichen Substances, The Bryologist, 89(2), 1986, 111-112 
29.PATRICHE, S., GHINEA, I.O., ADAM, G., GURAU, G., FURDUI, B., DINICA, R.M., REBEGEA, L.F., LUPOAE, M., Characterization of Bioactive Compounds from Romanian Cetraria islandica (L) Ach, Rev. Chim., 70(6), 2019, 2186-2191

30. JARACZ, S., PAN, L., SAMBANTHAMOORTHY, K., 2019, US Patent No. WO-2019018588A1

31.TAKANI, M., YAJIMA, T., MASUDA, H., YAMAUCHI, O., Spectroscopic and structural characterization of copper(II) and palladium(II) complexes of a lichen substance usnic acid and its derivatives. Possible forms of environmental metals retained in lichens, J. Inorg. Biochem., 91(1), 2002, 139-150

32. NATIC, M., TESIC, Z., ANDELKOVIC, K., BRCESKI, I., RADULOVIC, S., MANIC, S., SLADIC, D., Synthesis and biological activity of Pd(II) and $\mathrm{Cu}(\mathrm{II})$ complexes with acylhydrazones of usnic acid, Synth. React. Inorg. Met.-Org. Chem., 34(1), 2004, 101-113

33. BELJANSKI, V., ANDELKOVIC, K., POLETI, D., TESIC, Z., BRCESKI, I., SLADIC, D., Copper(II) complexes of usnic acid condensation products and their antibacterial activities, Synth.

React. Inorg. Met.-Org. Chem., 28(10), 1998, 1607-1617

34. KOCER, S., URUS, S., CAKIR, A., GUllUCE, M., DIGRAK, M., AlAN, Y., ASLAN, A., TUMER, M., KARADAYI, M., KAZAZH, C., DALI, H., The synthesis, characterization, antimicrobial and antimutagenic activities of hydroxyphenylimino ligands and their metal complexes of usnic acid isolated from Usnea longissimi, Dalton Trans., 43(16), 2014, 6148-6164

35. LAUTERWEIN, M., OETHINGER, M., BELSNER, K., PETERS, T., MARRE, R., In-Vitro Activities of the Lichen Secondary Metabolites Vulpinic Acid, (+)-Usnic Acid, and (-)-Usnic Acid against Aerobic and Anaerobic Microorganisms, Antimicrob. Agents Chemother., 39(11), 1995, 25412543

36. BARRERA TOMAS, M., TOMAS CHOTA, G.E., SHEEN CORTAVARRÍA, P., FUENTES BONILLA, P., INOCENTE CAMONES, M.A., SANTIAGO CONTRERAS, J.C., Synthesis of acylhydrazone from usnic acid and isoniazid and its antiMycobacterium tuberculosis activity, Rev. Colomb. Quim., 46(3), 2017, 17-21

37.TAKAI, M., UEHARA, Y., BEISLER, J. A., Usnic acid derivatives as potential antineoplastic agents, J. Med. Chem., 22, 1979, 1380

38.GHEORGHE, S., PETRE, J., STOICA, C., NITA-LAZAR, M., Risk screening of pharmaceutical compounds in Romanian aquatic environment, J. Environ. Monit., 188(6), 2016, 379

39.BANCIU, A.(CATRANGIU), NICULESCU, D., NITA-LAZAR, M., LUCACIU, I., STOICA, C., MIHAESCU, G., Potentially pathogenic and antibiotic resistant bacteria in the Danube Delta aquatic ecosystem, J. Environ. Prot. Ecol., 17(1), 2016, 127-135

40. NITA-LAZAR, M., GALAON, T., BANCIU, A., PAUN, I., STOICA, C., LUCACIU, I., Screening of various harmful compounds in a new bacterial biological model, J. Environ. Prot. Ecol., 17(1), 2016, 237-247

41. NITA-LAZAR, M., GHEORGHE, S., ANGHELACHE, A., BANCIU, A., STOICA, C., LUCACIU, I., Modulation of the Bacterial Defense Mechanisms by Various Chemical Structures, Rev. Chim., 67(8), 2016, 1454-1457

42. MiHAlACHE, M., GURAN, C., MEGHEA, A., BERCU, V., MOTELICA, L., HOLBAN, A.M., Complexes of $\mathrm{Cu}$ (II) with aketoglutaric acid and 1- (o-tolyl) biguanide - synthesis, characterization and biological activity, Rev. Chim., 70(10), 2019, 3603-3610

43. LEMOS, S.C., FRANCHI, S.J.S., NETTO, A.V.G., MAURO, A.E., TREU-FILHO, O., FREM, R.C.G., ALMEIDA, E.T., TORRES, C., Synthesis, characterization, thermal studies, and DFT calculations on $\mathrm{Pd}(\mathrm{II})$ complexes containing N-methylbenzylamine, Therm. Anal. Calorim., 106(2), 2011, 391-397

44.HERNANDEZ, J.O., CHOREN, E.A., Thermal-Stability of Some Platinum Complexes, Thermochim. Acta, 71(3), 1983, 265-272

45. RATHEE, N., VERMA, K.K., Studies on nickel (II) and palladium (II) complexes with some 
tetraazamacrocycles containing tellurium, J. Serb. Chem. Soc., 77(3), 2012, 325-333

46. CHANDRA, S., TYAGI, M., AGRAWAL, S., Spectral and antimicrobial studies on tetraaza macrocyclic complexes of Pd-II, Pt-II, Rh-III and Ir-III metal ions, J. Saudi Chem. Soc., 15(1), 2011, 49-54

47. AGARWAL, R.K., PRASAD, S., GOEL, N., Turk. J. Chem., 28, 2004, p.405

48. TAI, X.S., TAN, M.Y., Studies on synthesis, infrared and fluorescence spectra of new europium (III) and terbium (III) complexes with an beta-diketonate-type ligand, Spectrochim. Acta Part A, 61(8), 2005, 1767-1770

49. MOHAN, M., GUPTA, N.K., KUMAR, M., JHA, N.K., ANTHOLINE, W.E., Synthesis, magnetic and electrochemical properties of binuclear copper (II) complexes of pyridoxal hydrazones, Inorg. Chim. Acta, 197(1), 1992, 39-46

50. NAKAMOTO, K., Infrared and Raman Spectra of Inorganic and Coordination Compounds, 4th ed., Wiley, New York, 1986, p.231.

$\overline{\text { Manuscript received: } 19.12 .2019}$ 